\title{
Pengaruh Anti Oksidan Terhadap Kestabilan Sifat Fisis Bahan Polipaduan Polipropilena-Karet Alam: II. Studi Kristalinitas dan Struktur Molekul
}

\author{
Mashuri* \\ Jurusan Fisika, FMIPA, Institut Teknologi Sepuluh Nopember, Kampus ITS Sukolilo, Surabaya 60111
}

\begin{abstract}
Intisari
Telah dilakukan penelitian pengaruh anti osidan Irganok 1076 terhadap kestabilan kristalinitas dan struktur molekul bahan polipaduan polipropilena(PP)-karet alam(KA). Uji kestabilan dilakukan dengan penjemuran terhadap polipaduan selama 8 dan 12 minggu di alam terbuka. Polipaduan PP-KA(1:4) dan PP-KA(1:4)-Irganok $10768 \%$ dibuat dengan metode blending menggunakan alat rheologi pada temperatur $176{ }^{\circ} \mathrm{C}$, rotasi blending $30 \mathrm{rpm}$ selama 10 menit. Pengujian kristalinitas menggunakan X-Rays Difractometry dan pengujian struktur molekul menggunakan Fourier Transformation Infra Red (FTIR). Hasil menunjukkan terbentuknya gugus karbonil sebagai salah satu indikasi terdegradasinya polipaduan PP-KA oleh penjemuran selama 12 minggu dapat dihambat oleh anti oksidan Irganok 1076 dengan lebih kecilnya indek karbonil dibanding polipaduan tanpa Irganok. Terdegradasinya rantai polipaduan menyebabkan keteraturan susunan rantai molekul polipaduan PP-KA menurun tetapi untuk polipaduan PP-KA-Irganok 1076 penurunan derajat kristalinitasnya lebih kecil (sebesar $36 \%$ ) dibanding polipaduan PP-KA tanpa anti oksidan (sebesar 50\%). Perubahan kristalinitas dan struktur molekul yang diakibatkan oleh penjemuran di alam terbuka (sinar matahari) akan diikuti perubahan sifat fisis dan mekanik polipaduan PP-KA.
\end{abstract}

KATA KUNCI: polipaduan, anti oksidan, immiscible blends

\section{PENDAHULUAN}

Perkembangan ilmu dan rekayasa bahan memungkinkan untuk melakukan desain dan memodifikasi suatu bahan sesuai kebutuhan. Bahan polipaduan merupakan perpaduan antara beberapa polimer yang mempunyai jenis dan sifat yang berbeda, serta sifatnya yang berbeda dengan sifat polimer penyusunnya dan termasuk salah satu alternatif untuk pengembangan dari bahan polimer. Sifat polipaduan dapat dikendalikan dengan cara memilih bahan polimer penyusun polipaduan dan parameter sintesis, maka membuat bahan polipaduan ini banyak dipilih dan dikembangkan sebagai bahan alternatif untuk berbagai keperluan seperti keperluan konstruksi dan rekayasa bahan serta isolator.

Bahan polipaduan terdiri dari bahan polimer sebagai matrik dan polimer dengan jenis yang berbeda sebagai pengisi, yang dicampurkan ke dalam matrik. Sifat akhir bahan polipaduan yang dihasilkan sangat bergantung pada karakteristik polimer pengisi, meliputi konsentrasi dan jenis, dan sifat adesi antar muka matrik-pengisi yang menentukan kompaktibilitas polipaduan serta tingkat penyebaran polimer pengisi dalam matrik. Sejauh ini telah dilakukan beberapa penelitian bahan polipaduan yang mengkaji sifat mekanik [1-3], sifat kompaktibilitas polipaduan [4], sifat termal $[1,5,6]$.

Dalam penelitian yang mengkaji tingkat kekompakan (miscible) dari polipaduan telah dilakukan eksperimen pada

*E-MAIL: mash@physics.its.ac.id polipaduan polikarbonat (PC)-akrilonitril butadiene stirena (ABS), polivinil klorida(PVC)-akrilonitril butadiene stirena(ABS), poliamida (PA)-akrilonitril butadiene stirena(ABS), polivinil klorida (PVC)-polietilena (PE). Hasil menunjukkan bahwa polipaduan PC-ABS, PA-ABS dan PVC-PE termasuk jenis polipaduan tak kompak (immiscible Difraktogram) dari hasil uji XRD bahan polipaduan PP-KA dan PP-KA-Irganok $10768 \%$ sebelum dan sesudah mengalami penjemuran selama 12 minggu ditunjukkan pada Gambar 1. Untuk mengetahui pengaruh pemberian bahan anti oksidan irganok 1076 terhadap struktur kristal bahan polipaduan yang mengalami perlakuan penjemuran di alam terbuka (di bawah sinar matahari) dapat diketahui dengan menghitung nilai derajat kristalinitas dari difraktogram bahan polipaduan PP-KA dan PP-KAIrganok $10768 \%$. Hasil penghitungan derajat kristalinitas dari kedua polipaduan dengan metode standart dalam ditunjukkan pada Tabel 1.blends), sedangkan PVC-ABS termasuk polipaduan jenis kompak (miscible blends) [2, 4]. Dalam penelitian yang mengkaji sifat tarik dari polipaduan telah dilakukan eksperimen pengukuran kebergantungan tegangan luluh, kekuatan tarik dan regangan patah serta modulus elastik pada konsentrasi bahan pengisi. Hasil menunjukkan bahwa polimer pengisi berperan dalam menurunkan tegangan luluh, kekuatan tarik dan regangan patah tetapi meningkatkan modulus elastik immiscible blends $[3,6]$. Sementara itu pada polipaduan jenis kompak (miscible blends) polimer pengisi lebih mampu meningkatkan kekuatan tarik dan regangan patah dibanding dengan polipaduan jenis tak kompak (immiscible blends), hal ini dikarenakan pada saat mendapatkan beban tarikan terjadi sobekan awal (craze) pada antar muka polimer matrik-pengisi pada polipaduan jenis tak kompak [7]. 
Untuk meningkatkan sifat tarik dari bahan polipaduan, terdapat beberapa cara yang dapat dilakukan seperti menumbuhkan rantai ikat silang dengan agen ikat silang (crosslink agent), meningkatkan daya kekompakan matrik-pengisi dengan menambahkan bahan pengompak (compactibilizer), dan meningkatkan penyebaran polimer pengisi dengan menggunakan agen pendispersi fasa padat (SPD, solid phase dispersant)(Billmeyer, 1984). Pada penelitian pengaruh rantai ikat silang terhadap sifat kuat tarik polietilena (PE), rantai ikat silang dapat meningkatkan kekuatan tarik dan regangan patah serta temperatur leleh, hal ini disebabkan bentuk tiga dimensi rantai ikat silang lebih mampu mereduksi beban tarikan dari luar. Ghaffar, et.al, 1981, telah melakukan penelitian perbaikan sifat mekanik dari polipaduan PE (polietilena) - PVC (polivinil klorida) dengan menggunakan cara mensinergikan bahan pengompak (compactibilizer) dan penumbuh rantai ikat silang (crosslink agent) dan hasilnya sifat kuat tarik polipaduan tersebut meningkat. Hal ini terjadi karena polimer matrik sebagai tempat pengumpulan tegangan mampu mereduksi tegangan serta adesi antar muka matrik-pengisi lebih dapat terbentuk dengan baik [8].

Polipaduan PP (polipropilena) - KA (karet alam) termasuk jenis polipaduan tak kompak, tingkat sebaran KA sebagai pengisi masih kurang homogen dan gaya ikat permukaan kontak fasa matrik-pengisi kurang terbentuk dengan sempurna sehingga menimbulkan titik-titik lemah yang mendegradasikan sifat mekanik secara keseluruhan[3]. Polipaduan PPKA mempunyai sifat transparansi terhadap sinar dan mempunyai kemampuan mulur putus yang lebih baik. Salah satu aplikasinya digunakan dibidang teknologi pertanian, contohnya sebagai plastik penutup lahan ketika dilakukan penanaman lombok atau melon. Degradasi sifat mekanik bahan polipaduan saat diaplikasikan di lapangan disebabkan oleh serangan sinar ultra violet dan reaksi oksidasi dengan udara luar [9-11], di samping itu sifat ketidakkompakan polimer matrik dengan polimer yang dipadukan juga merupakan potensi terjadinya degradasi sifat mekanik polipaduan dengan cepat.

Pada makalah ini dilaporkan hasil penelitian pengendalian kecepatan degradasi sifat mekanik bahan polipaduan PP-KA yang diakibatkan oleh serangan reaksi oksidasi, pengendalian yang dilakukan dengan menghambat terjadinya reaksi oksidasi. Upaya tersebut dilakukan dengan menambahkan bahan aditif antioksidan pada polipaduan PP-KA yaitu Irganok 1076.

Perilaku sifat mekanik dan fisis akhir yang dihasilkan dari proses sintesis suatu bahan polipaduan sangat bergantung pada karakteristik bahan polimer matrik, bahan polimer pengisi, keadaan antar muka matrik-pengisi, tingkat distribusi polimer pengisi dalam matrik, konsentrasi polimer pengisi (filler), proses pembuatan dan pemberian bahan aditif. Hal ini terutama pada bahan polipaduan jenis tak kompak (immiscible blends) seperti polipaduan PP-KA. Untuk mengkaji permasalahan tersebut pada makalah ini dititik beratkan hasil penelitian pengaruh konsentrasi KA sebagai fasa filler dan konsentrasi irganok 1076 sebagai antioksidan terhadap kestabilan kristalinitas dan struktur molekul polipaduan PP-KA pasca mengalami perlakuan penjemuran dalam rentang waktu 12 minggu di alam terbuka.

\section{METODE PENELITIAN}

\section{A. Bahan}

1. Polipropilena berbentuk butiran bening dengan MFI 4 gr/10 minutes, temperatur leleh $176{ }^{\circ} \mathrm{C}$, densitas 0,896 $\mathrm{gr} / \mathrm{cm}^{3}$, produksi PT Tri Polyta Indonesia Tbk, sebagai bahan matrik.

2. Karet Alam berbentuk lembaran dengan temperatur leleh $130{ }^{\circ} \mathrm{C}$, densitas $0,792 \mathrm{gr} / \mathrm{cm}^{3}$, dari latex pohon karet Kalimantan, sebagai bahan pengisi (filler).

3. Irganok 1076 berbentuk serbuk putih dengan densitas $0,480 \mathrm{gr} / \mathrm{cm}^{3}$, sebagai bahan anti oksidan

\section{B. Pembuatan dan Pengujian Sampel}

Sampel yang dibuat terdiri dari 2 (dua) macam yaitu pertama, polipaduan PP-KA tanpa anti oksidan dengan konsentrasi KA $20 \%$ vol, dan kedua polipaduan PP-KA (4:1) dengan anti oksidan $8 \%$ vol. Komposisi masing-masing sampel merupakan konsentrasi optimal dari penelitian terdahulu[3] ditimbang dengan neraca timbang digital merk Precisa 3000 D Swiss Quality kapasitas $3 \mathrm{~kg}$, kemudian dimasukkan ke dalam alat Rheologi 30 rpm kapasitas 60 gr untuk mengalami proses blending pada temperatur $176^{\circ} \mathrm{C}$ dalam waktu 10 menit dengan rotasi blending $30 \mathrm{rpm}$ (proses ini dilakukan di Dinas Pengendalian Mutu Petrokimia-DPMP PT Pertamina Pulo Gadung). Tahap berikutnya hasil proses blending dimasukkan ke alat cetak tekan panas dengan pembebanan $500 \mathrm{~kg} / \mathrm{cm}^{2} \mathrm{se}-$ lama 3 menit dan dipindahkan ke dalam alat cetak dingin dengan pembebanan hingga 16 ton dalam waktu 3 menit hingga diperoleh bentuk sampel berupa film tipis dengan ketebalan $1 \mathrm{~mm}$, menggunakan alat Hidrolik Press merk Toyoseiki Jepang. Untuk sampel kedua dilakukan penjemuran di alam terbuka dengan rentang waktu 8 dan 12 minggu yang dilakukan di Surabaya, bulan Juni, Juli dan Agustus 2004.

Selanjutnya semua sampel dilakukan pengujian derajat kristalinitas dengan alat XRD (X Rays Difractometry) merk Phillips X'Pert MPD Belanda dan sampel dilakukan pengujian stuktur molekul menggunakan alat FTIR (Fourier Tranformation Infra Red) merk Shimadzu tipe 8201 PC.

\section{HASIL DAN PEMBAHASAN}

\section{A. Analisis derajat kristalinitas polipaduan sebelum dan sesudah penjemuran}

Kristalinitas merupakan angka yang menggambarkan kandungan fasa kristalin dari suatu bahan. Bahan polipaduan PPKA seperti pada bahan polimer termasuk jenis semikristalin. Fasa kristalin suatu bahan menentukan sifat fisis yang dimiliki bahan tersebut, apabila suatu bahan mengalami perlakuan eksternal yang menyebabkan terjadinya perubahan fasa krista- 
lin maka sifat fisis bahan tersebut akan mengalami perubahan juga [1].

Kristalinitas suatu bahan dapat diamati dengan melakukan pengujian struktur kristal dengan menggunakan alat XRD. Untuk menghitung derajat kristalinitas dari difrakatogram hasil pengujian dapat dilakukan dengan beberapa metode, salah satunya adalah metode standart dalam (internal standart) [12]. Penghitungan nilai derajat kristalinitas dengan metode standart dalam menggunakan rumus sebagai berikut:

$$
X=\left(1-\frac{S_{a m o r f}}{S_{\text {total }}}\right)
$$

dengan

$$
\begin{array}{r}
S_{\text {amorf }}=\sum\left[I_{\text {amorf }}(2 \theta) \cdot I(2 \theta)\right] \cdot \Delta 2 \theta \\
S_{\text {total }}=\sum[I(2 \theta)] \cdot I(2 \theta)
\end{array}
$$

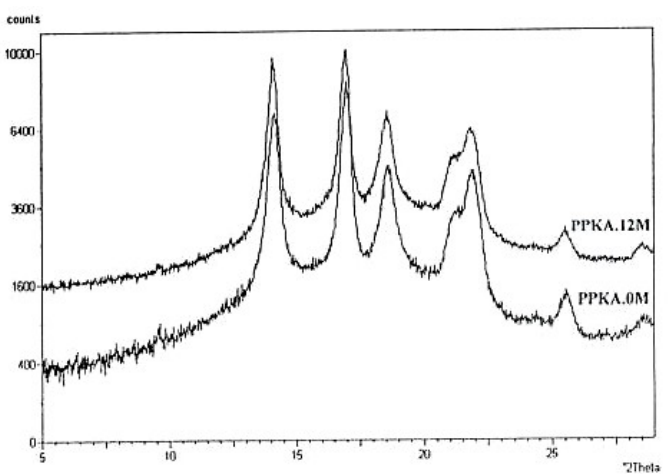

(a)

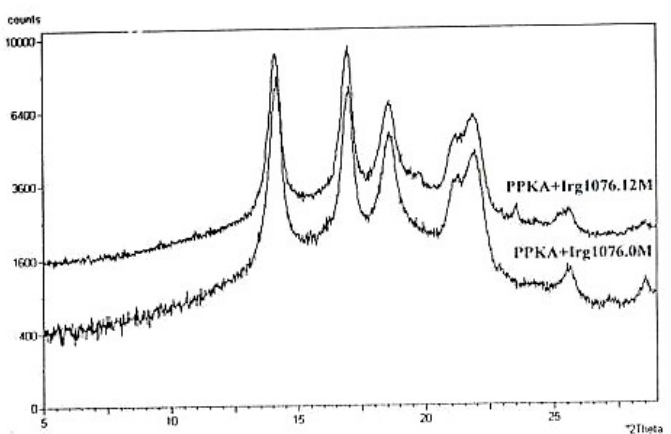

(b)

Gambar 1: Difraktogram polipaduan (a). PP-KA dan (b). PP-KAIrganok $10768 \%$

Difraktogram dari hasil uji XRD bahan polipaduan PP-KA dan PP-KA-Irganok 1076 8\% sebelum dan sesudah mengalami penjemuran selama 12 minggu ditunjukkan pada Gambar 1. Untuk mengetahui pengaruh pemberian bahan anti oksidan irganok 1076 terhadap struktur kristal bahan polipaduan yang mengalami perlakuan penjemuran di alam terbuka (di bawah sinar matahari) dapat diketahui dengan menghitung nilai derajat kristalinitas dari difraktogram bahan polipaduan PP-KA dan PP-KA-Irganok 1076 8\%. Hasil penghitungan derajat kristalinitas dari kedua polipaduan dengan metode standart dalam ditunjukkan pada Tabel 1.

Dari Gambar 1(a) memperlihatkan penurunan fasa kristalin yang diikuti peningkatan fasa amorfphous, ini sesuai hasil perhitungan dengan persamaan 1 seperti pada Tabel 1, terlihat bahwa polipaduan PP-KA(20\%) mempunyai nilai derajat kristalinitas yang lebih tinggi dibanding dengan PP-KA(20\%Irganok 1076 8\%. Pemberian Irganok sebagai bahan anti oksidan menyebabkan struktur kristalinitas polipaduan berkurang akan tetapi pada saat polipaduan mengalami perlakuan penjemuran selama 12 minggu dapat menghambat penurunan derajat kristalinitas bahan. Ini menunjukkan serangan radiasi sinar ultra violet dan temperatur matahari yang dapat menyebabkan pemutusan rantai-rantai dalam molekul polimer paduan sehingga ketidakteraturan struktur kristal menurun dapat diminimalkan dengan cara menghambat laju pemutusan rantai-rantai polipaduan oleh Irganok. Fenomena penghambatan terjadinya perubahan kristalinitas oleh irganok dapat dilihat dengan membandingkan penurunan derajat kristalinitas polipaduan PP-KA pada penjemuran 12 minggu sebesar 50\% sedangkan polipaduan PP-KA-irganok 1076 8\% sebesar 36\% terhadap derajat kristalinitas polipaduan yang tidak mengalami penjemuran.

\section{B. Analisis perubahan struktur molekul polipaduan sebelum dan sesudah penjemuran}

Perubahan sifat fisis yang dialami bahan polipaduan PP-KA dengan dan tanpa irganok 1076 yang telah mengalami penjemuran di alam terbuka seperti sifat mekanik dan morfologi [3] dan penurunan nilai derajat kristalinitas tidak terlepas dari perubahan struktur internal dari bahan tersebut. Perubahan struktur internal suatu bahan dapat digambarkan oleh perubahan struktur molekul dimana dapat diamati dengan melakukan pengujian menggunakan alat FTIR.

Gambar 2 merupakan spectrogram hasil uji dengan FTIR dari bahan polipaduan PP-KA(4:1) dan PP-KA(4:1)-Irganok $10768 \%$ yang tidak mengalami penjemuran. Identifikasi gugus molekul ditunjukkan oleh Tabel 2. Dari Tabel 2, teramati bahwa pada polipaduan PP-KA tidak terdapat gugus karbonil $(\mathrm{C}=\mathrm{O})$ pada bilangan gelombang $1730-1710 \mathrm{~cm}^{-1}$, ini menunjukkan bahwa polipaduan ini belum mengalami degradasi dari luar, sedang pada polipaduan PP-KA-irganok $8 \%$ terdapat kandungan gugus karbonil pada bilangan gelombang 1726 $\mathrm{cm}^{-1}$. Gugus karbonil ini bukan produk dari degradasi, tetapi muncul akibat adanya anti oksidan irganok 1076, ini menunjukkan bahwa gugus karbonil merupakan bagian dari irganok 1076 selain itu juga muncul gugus $C-H_{s t r}$ (aldehid) $\left(2870,34 \mathrm{~cm}^{-1}\right), \mathrm{C}=\mathrm{O}\left(1726,45 \mathrm{~cm}^{-1}\right)$ dan $-\mathrm{C}-\mathrm{H}$ in plane deformation (aromatic) $\left(1176,68 \mathrm{~cm}^{-1}\right)$.

Dari Gambar 3a dan Tabel 3 memperlihatkan pengaruh penjemuran selama 8 minggu menyebabkan munculnya gugus baru yaitu C-H Stretching (aldehid) $\left(2870,34 \mathrm{~cm}^{-1}\right)$ dan gugus $\mathrm{C}-\mathrm{H}$ in plane def (aromatik) $\left(997,28 \mathrm{~cm}^{-1}\right)$ yang dii- 
Tabel I: Derajat Kristalinitas Polipaduan PP-KA

\begin{tabular}{lccc}
\hline \hline No & Polipaduan & \multicolumn{2}{c}{ Derajad Kristalinitas } \\
& & Penjemuran 0 minggu & Penjemuran 12 minggu \\
\hline 1 & PP-KA(rm 20\% ) & 26,65799 & 13,71367 \\
2 & PP-KA(rm 20\% )-Irganok 1076 8\% & 25,08350 & 16,52852 \\
\hline \hline
\end{tabular}

Tabel II: Identifikasi gugus fungsional polipaduan PP-KA (4:1) sebelum penjemuran

\begin{tabular}{|c|c|c|c|c|}
\hline \multirow[t]{2}{*}{ Nama Gugus } & \multicolumn{2}{|c|}{ PP-KA } & \multicolumn{2}{|c|}{ PP-KA-Irgonak $10678 \%$} \\
\hline & Bil.Gelb. $\left(\mathrm{cm}^{-1}\right)$ & $\% \mathrm{~T}$ & Bil.Gelb. $\left(\mathrm{cm}^{-1}\right)$ & $\% \mathrm{~T}$ \\
\hline$\overline{\mathrm{OH}}$ & 3414,31 & 68,7 & 3410,45 & 76,5 \\
\hline $\mathrm{CH}_{2}\left(\mathrm{C}-\mathrm{H}_{\text {str }}\right)$ & 2930,14 & 68,7 & 2920,49 & 73,8 \\
\hline$C-H_{s t r}($ aldehid $)$ & - & - & 2851,05 & 79,1 \\
\hline $\mathrm{C}=\mathrm{O}$ & - & - & 1726,45 & 84,7 \\
\hline $\mathrm{C}=\mathrm{C}$ & 1631,93 & 68,7 & 1631,93 & 85,4 \\
\hline$C H_{3 a s y m}\left(C-H_{\text {def }}\right)$ & 1452,53 & 68,7 & - & - \\
\hline $\mathrm{CH}_{3}\left(\mathrm{C}-\mathrm{H}_{\text {def }}\right)$ & 1379,23 & 68,7 & 1377,17 & 85,5 \\
\hline$-C-$ Hinplanedef (aromatic) & - & - & 1176,68 & 85,2 \\
\hline Skeletal $\left(\mathrm{CH}_{3}-\mathrm{C}-\mathrm{CH}_{3}\right)$ & 1167,04 & 75,2 & - & - \\
\hline$=\mathrm{CH}_{2 d e f}$ & 841,04 & 74,9 & - & - \\
\hline$C H=C H_{c i s}$ & 686,72 & 76,2 & 688,65 & 86,1 \\
\hline
\end{tabular}

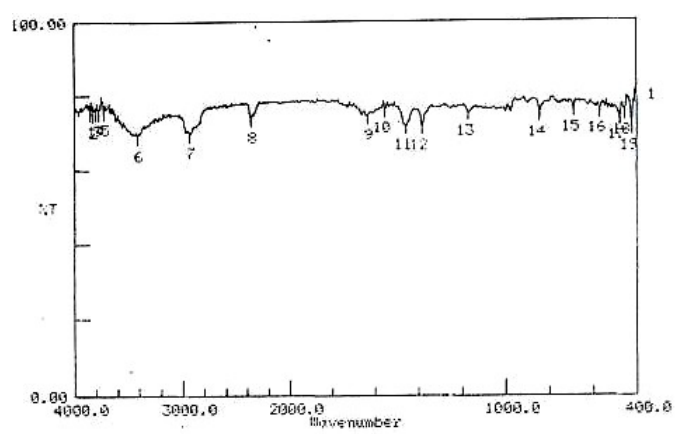

(a)

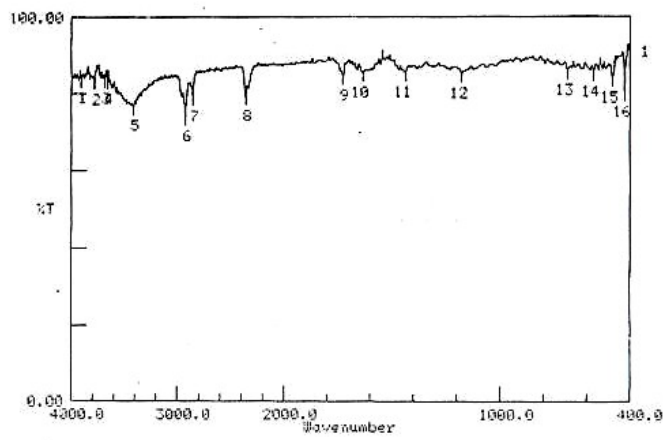

(b)

Gambar 2: (a). FTIR PP-KA(4:1) tanpa penjemuran,(b). FTIR PPKA(4:1)-Irganok $10768 \%$ tanpa penjemuran

kuti peningkatan absorbansi dari gugus $\mathrm{C}-\mathrm{H}$ str $(2870,34$ $\left.\mathrm{cm}^{-1}\right)$, CH3(C-H def) $\left(1377,30 \mathrm{~cm}^{-1}\right)$ dan $\mathrm{CH} 3$ asym(C$\mathrm{H}$ def) $\left(1460 \mathrm{~cm}^{-1}\right)$ dari polipaduan PP-KA. Untuk polipaduan PP-KA-Irganok 1076 8\% menyebabkan munculnya gugus CH3(C-H str) $\left(2961,00 \mathrm{~cm}^{-1}\right)$ serta peningkatan absor-

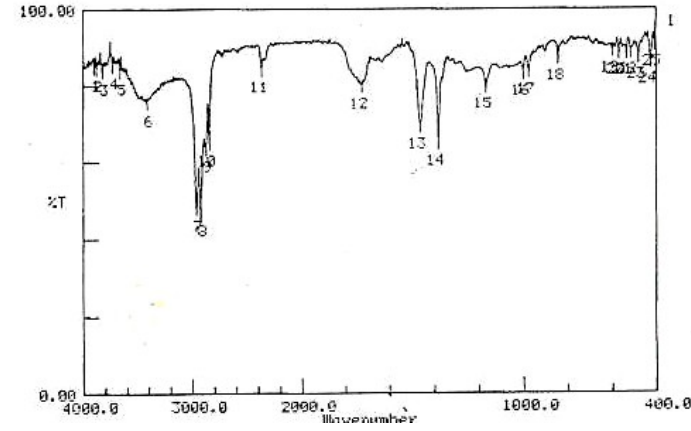

(a)

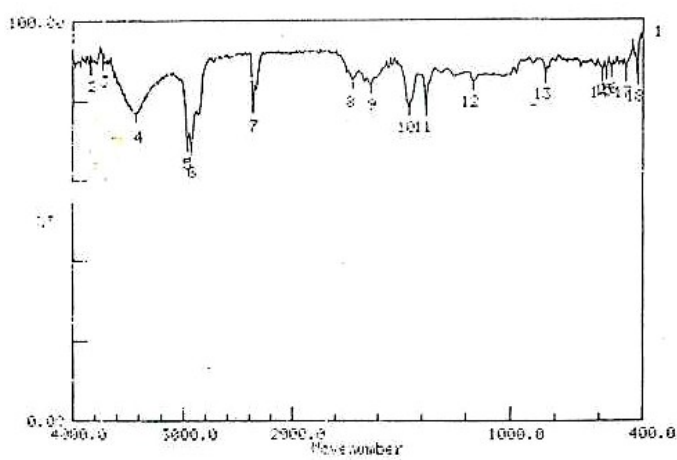

(b)

Gambar 3: (a). FTIR PP-KA(4:1) penjemuran 8 minggu, (b). FTIR PP-KA(4:1)-Irganok $10768 \%$ penjemuran 8 minggu

bansi dari gugus $\mathrm{CH} 2$ (C-H str) $\left(2924,35 \mathrm{~cm}^{-1}\right)$, gugus $\mathrm{CH} 3$ asym (C-H def) $\left(1452,53 \mathrm{~cm}^{-1}\right.$ dan gugus $\mathrm{CH} 3(\mathrm{C}-\mathrm{H}$ def) $\left(1377,30 \mathrm{~cm}^{-1}\right)$. Nilai absorbansi berbanding terbalik dengan transmisi yaitu[12] : 
Tabel III: Identifikasi gugus fungsional polipaduan PP-KA (4:1) penjemuran 8 minggu

\begin{tabular}{|c|c|c|c|c|}
\hline \multirow[t]{2}{*}{ Nama Gugus } & \multicolumn{2}{|c|}{ PP-KA } & \multicolumn{2}{|c|}{ PP-KA-Irgonak 1067 8\% } \\
\hline & Bil.Gelb. $\left(\mathrm{cm}^{-1} \mathrm{t}\right)$ & $\% \mathrm{~T}$ & Bil.Gelb. $\left(\mathrm{cm}^{-1} \mathrm{t}\right)$ & $\% \mathrm{~T}$ \\
\hline $\mathrm{OH}$ & 3412,38 & 75,7 & 3412,38 & 75,8 \\
\hline $\mathrm{CH}_{3}\left(\mathrm{C}-\mathrm{H}_{s t r}\right)$ & 2961,00 & 48,5 & - & - \\
\hline $\mathrm{CH}_{2}\left(\mathrm{C}-\mathrm{H}_{s t r}\right)$ & 2920,49 & 47,4 & 2916,00 & 69,2 \\
\hline$C-H_{s t r}($ aldehid $)$ & 2870,34 & 63,8 & - & - \\
\hline$C-H_{\text {str }}($ aldehid $)$ & 2839,47 & 65,3 & - & - \\
\hline $\mathrm{C}=\mathrm{O}$ & 1724,52 & 80,3 & 1724,52 & 84,7 \\
\hline $\mathrm{C}=\mathrm{C}$ & - & - & 1631,93 & 84 \\
\hline$C H_{3 a s y m}\left(C-H_{\text {def }}\right)$ & 1460,25 & 69,8 & 1452,53 & 78,2 \\
\hline $\mathrm{CH}_{3}\left(\mathrm{C}-\mathrm{H}_{\text {def }}\right)$ & 1377,30 & 65,4 & 1377,30 & 78,4 \\
\hline$-C-$ Hinplanedef(aromatic) & 997,28 & 83,7 & - & - \\
\hline Skeletal $\left(\mathrm{CH}_{3}-\mathrm{C}-\mathrm{CH}_{3}\right)$ & 1167,04 & 80,1 & 1165,11 & 84,8 \\
\hline$C-H_{d e f}($ aldehid $)$ & 947,14 & 80,4 & 688,65 & - \\
\hline$=\mathrm{CH}_{2 d e f}$ & 841,04 & 87,7 & 842,97 & 86,6 \\
\hline
\end{tabular}

$$
\begin{array}{r}
\% T=\frac{\text { intensitas }}{\text { intensitasorisinal }} \\
A=\log \left(\frac{\text { intensitasorisinal }}{\text { intensitas }}\right)
\end{array}
$$

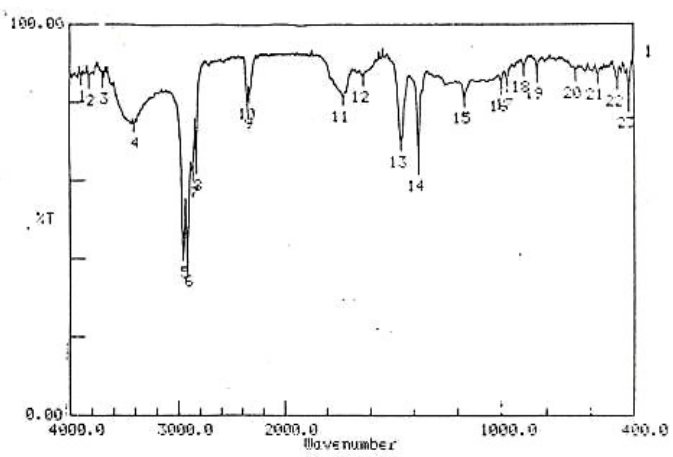

(a)

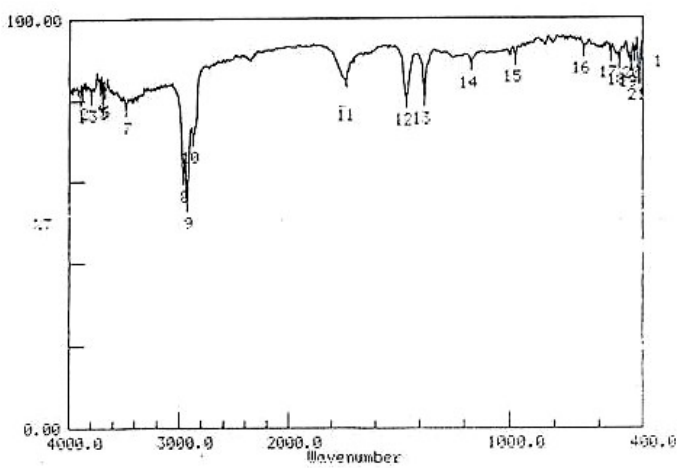

(b)

Gambar 4: (a). FTIR PP-KA(4:1) penjemuran 12 minggu, (b). FTIR PP-KA(4:1)-Irganok $10768 \%$ penjemuran 12 minggu

Dari Gambar 4a dan Tabel 4 memperlihatkan pengaruh penjemuran selama 12 minggu menyebabkan munculnya gugus C-H out plane def. (aromatik) $\left(900,84 \mathrm{~cm}^{-1}\right)$ dan
$\mathrm{C}=\mathrm{C}\left(1631,93 \mathrm{~cm}^{-1}\right)$. Sedangkan untuk polipaduan PP-KAIrganok 1076 terjadinya penumbuhan gugus baru C-H str (aldehid) $\left(2868,41 \mathrm{~cm}^{-1}\right)$ dan $\mathrm{C}-\mathrm{H}$ def (aldehid) $\left(974,14 \mathrm{~cm}^{-1}\right)$ serta tidak munculnya gugus $\mathrm{C}=\mathrm{C}\left(1631,93 \mathrm{~cm}^{-1}\right)$ dan $=$ $\mathrm{CH}_{2}\left(842,97 \mathrm{~cm}^{-1}\right)$ seperti pada Gambar 4b. Pengaruh penjemuran selama 12 minggu menyebabkan peningkatan absorbansi pada gugus $\mathrm{CH}_{3}\left(\mathrm{C}-\mathrm{H}\right.$ str) $\left(2957,14 \mathrm{~cm}^{-1}\right), \mathrm{CH}_{2}(\mathrm{C}-\mathrm{H}$ str) $\left(2924,35 \mathrm{~cm}^{-1}\right)$, gugus $\mathrm{CH}_{3} \operatorname{asym}(\mathrm{C}-\mathrm{H}$ def $)(1460,25$ $\left.\mathrm{cm}^{-1}\right)$ dan $\mathrm{CH}_{3}(\mathrm{C}-\mathrm{H}$ def $)\left(1377,30 \mathrm{~cm}^{-1}\right)$ dari polipaduan PP-KA-Irganok 1076.

Dari spectra-spektra FTIR (Gambar 2, 3, 4) terlihat terdapatnya gugus - gugus baru yang terbentuk pada polipaduan setelah mengalami penjemuran di alam terbuka. Ini sebagai akibat terjadinya degradasi rantai molekul polipaduan yang disebabkan oleh factor sinar ultra violet, foton dan termal dari sinar matahari.

Ikatan rantai di dalam makromolekul mempunyai energi $300 \mathrm{~kJ} / \mathrm{mol}$ dan $500 \mathrm{~kJ} / \mathrm{mol}$ sedangkan sinar ultra violet dari sinar matahari mempunyai panjang gelombang $400 \mathrm{~nm}$ mempunyai energi yang besar yaitu 3,03 $-6,06 \mathrm{eV}$, sehingga dapat memindahkan electron ke orbital berenergi yang tinggi. Energi ini mampu memutuskan ikatan dalam makromolekul dan membentuk radikal bebas.

Foton dari sinar matahari mengakibatkan polimer terfotodegradasi sehingga menyebabkan terjadinya perubahan fisis dan kimia. Proses fotodegradasi terjadi dalam tiga tahap yaitu penyerapan foton, reaksi fotokimia primer yang meliputi keadaan elektronik tereksitasi dan reaksi skunder dari radikal, ion molekul, ion dan elektron yang dihasilkan oleh proses fotokimia primer.

Faktor termal dari matahari sangat mempengaruhi terjadinya proses degradasi. Termal diserap oleh polipaduan dalam bentuk energi panas. Jika energi yang diserap sangat tinggi akan mengakibatkan elektron dalam bahan tereksitasi, dan jika berlangsung lama dan kontinyu dapat mengakibatkan terputusnya ikatan dalam molekulnya. Ini sangat bergantung dari sifat ikatan dan gugus dalam rantai polimer. Pemutusan ikatan rantai molekul mengakibatkan terbentuknya radikal bebas. Dengan adanya oksigen di udara mengakibatkan polimer akan teroksidasi sehingga mengakibatkan terbentuknya 
Tabel IV: Nilai Indeks Karbonil Polipaduan PP-KA dan PP-KA-irganok 1076 sebelum dan setelah penjemuran

\begin{tabular}{cccr}
\hline \hline Bahan & & Nilai Indeks Karbonil & Penjemuran 12 minggu \\
& Penjemuran 0 minggu & Penjemuran 8 minggu & 2,527 \\
PP-KA(1:4) & 0 & 2,469 & 1,986 \\
\hline \hline
\end{tabular}

gugus-gugus baru.

Dari data-data spectra FTIR di atas, diperoleh serapan gugus karbonil $(\mathrm{C}=\mathrm{O})$ setelah mengalami penjemuran. Ini menunjukkan bahwa serapan gugus karbonil mengalami pertumbuhan seiring dengan pertumbuhan gugus yang lain setelah penjemuran. Besarnya serapan gugus karbonil dapat dijadikan sebagai parameter laju degradasi. Pengukuran degradasi pada polimer ditentukan oleh indeks karbonil yaitu dengan membandingkan absorban gugus karbonil dengan absorban pembanding (serapan 2020-2000 $\mathrm{cm}^{-1}$ ) [13]. Pertumbuhan gugus karbonil dapat dihubungkan dengan hilangnya sifat mekanis utamanya karena pemutusan ikatan, karena makin besar gugus ini menyebabkan polimer lebih kaku tapi rapuh serta penurunan derajat kristalinitas bahan. Hasil perhitungan nilai indeks karbonil dari spectra-spektra FTIR di atas ditunjukkan pada Tabel 4. Dari Tabel 4 memperlihatkan semakin lama penjemuran dengan sinar matahari menyebabkan semakin terdegradasinya rantai polipaduan, sedangkan dengan pemberian bahan anti oksidan irganok 1076 dapat menghambat laju terjadinya degradasi pada rantai-rantai polipaduan. Hal ini ditunjukkan dengan sedikitnya nilai indeks karbonil dari polipaduan PPKA.

\section{SIMPULAN}

Terbentuknya gugus karbonil sebagai salah satu indikasi terdegradasinya polipaduan PP-KA oleh penjemuran selama 12 minggu dapat dihambat oleh bahan anti oksidan Irganok 1076. Terdegradasinya rantai polipaduan menyebabkan keteraturan susunan rantai molekul polipaduan PP-KA menurun tetapi untuk polipaduan PP-KA-Irganok 1076 penurunan derajat kristalinitasnya lebih kecil (sebesar 36\%) dibanding polipaduan PP-KA tanpa anti oksidan (sebesar 50\%). Perubahan kristalinitas dan struktur molekul yang diakibatkan oleh penjemuran di alam terbuka (sinar matahari) akan diikuti perubahan sifat fisis dan mekanik polipaduan PP-KA.
[1] M.Suhartini, M.Utama, M.Sumarti, S.Susilowati, T.Puspitasari, D.Listina dan Marsongko, Studi Sifat fisik, Mekanik dan Termal Terhadap Campuran Kopolimer Karet Alam Stiren Dan Polietilena (LDPE), Penelitian dan Pengembangan Aplikasi Isotop, 1999.

[2] Pujiono dan Mashuri, Pengaruh Penambahan Polietilene, Polipropilena dan Polistirena Terhadap Sifat Termal dan Mekanik ABS dalam Bentuk Polipaduan, Presentasi Ilmiah di BATAN, Serpong, 2000.

[3] Mashuri, A.Marini dan Sudirman, Pengaruh Anti Oksidan Terhadap Kestabilan Sifat Fisis Bahan Polipaduan PolipropilenaKaret Alam: I. Studi Morfologi dan Sifat Mekanik, Jurnal Fisika Dan Aplikasinya, Vol. 1 (2), 2005.

[4] E. Kroeze, G. ten Brinke and G. Hadziioannou, Polymer, Vol. 38, No. 2, 1997.

[5] C. Chuai, K.Almdal, J.L.Jorgensen,Journal of Applied Polymer Science, vol. 91, pp. 609-620, 2004

[6] V.Mano, M.E.S.Ribeiro e Silva, N.Barbani, P.Giusti,Journal of
Applied Polymer Science, vol. 91, pp. 501-505, 2004.

[7] S.Tantayanon and S.Juikham,Journal of Applied Polymer Science, vol.91, pp. 510-515, 2004

[8] G. Scott, Development in Polymer Stabilization, Applied Science Publisher, London, 1979.

[9] M.H. Christopher dan C.T. Ho, Natural Antioxidant, AOCS, Ohio, 1985.

[10] J.D.Dziezak, Antioxidant, the Ultimate Answer Oxidation, 3th ed. John Wiley \& Sons, Inc, New York, 1982.

[11] J.F.Rabek,Photodegradtion of Polymer, Springer Verlag, New York, 1996.

[12] M. Iguchi,Workshop Text for X Rays Difraction (revised), LIPI, ASEAN, JICA, Bandung, 1990.

[13] Ralp J. Fessenden \& Joan S. Fessenden, Kimia Organik Jilid I, Alih Bahasa Aloysius Hadyana P, Edisi ketiga, Penerbit Erlangga, Jakarta, 1990. 